\title{
СРАВНИТЕЛЬНО-ПРАВОВОЙ АНАЛИЗ ЗАКОНОДАТЕЛЬСТВА РЕГУЛИРУЮЩЕГО ПРЕСТУПЛЕНИЯ ПРОТИВ ОБЩЕСТВЕННОЙ НРАВСТВЕННОСТИ В ГОСУДАРСТВАХ БЛИЖНЕГО ЗАРУБЕЖЬЯ: ЛАТВИИ, ЛИТВЫ, ГРУЗИИ, АРМЕНИИ, КАЗАХСТАНА, АЗЕРБАЙДЖАНА, КИРГИЗИИ, ТАДЖИКИСТАНА, БЕЛОРУССИИ, УЗБЕКИСТАНА, ТУРКМЕНИИ
}

\section{COMPARATIVE LEGAL ANALYSIS \\ OF LEGISLATION REGULATING CRIMES \\ AGAINST PUBLIC MORALS \\ IN NEIGHBORING COUNTRIES: LATVIA, LITHUANIA, GEORGIA, ARMENIA, \\ KAZAKHSTAN, AZERBAIJAN, KYRGYZSTAN, TAJIKISTAN, BELARUS, UZBEKISTAN, TURKMENISTAN}

\section{O. Yaroshenko}

Summary: The article examines the experience of legislative regulation of crimes against public morality in the criminal laws of states and neighboring countries. Features of the criminal legislation of these states allows the use of this legal experience in order to protect the individual from sexual assault in our country. Currently, personal protection is one of the most relevant areas, both in foreign and domestic criminal law. The author expresses his position on the most pressing issues in the field of crimes against public morality.

Keywords: against public morality, cruel or violent treatment of minors, coercion to engage in prostitution, involvement of a person in prostitution, pimping, public health, organization or maintenance of brothels for prostitution, trafficking in child pornography, spiritual and moral health of a person, legal experience, features qualifications, crimes against public morality.

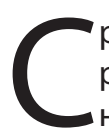

равнительно-правовой анализ законодательства регулирующего преступления против общественной нравственности в государствах ближнего зарубежья позволяет сказать, что нравственность является самостоятельным объектом уголовно-правовой охраны и подлежит особой правовой защите.

Проведенное нами исследование позволяет предложить некоторые изменения в главу 25 Уголовного кодекса Российской Федерации РФ в целях обеспечения защиты прав и интересов граждан от сексуальной злоупотреблений и эксплуатаций, которые наносят вред их

\section{Ярошенко Ольга Николаевна \\ К.ю.н., дочент, Нижегородский областной суд olga.yaroshenko.74@bk.ru}

Аннотация: В статье исследуется опыт, законодательного регулирования преступлений против общественной нравственности в уголовных законах государств, ближнего зарубежья. Особенности уголовного законодательства этих государств позволяет использовать данный правовой опыт в целях охраны личности от сексуальных посягательств и в нашей стране. В настоящее время защита личности является одним из наиболее актуальных направлений, как в зарубежном, так и отечественном уголовном праве. Автор высказывает свою позицию по наиболее актуальным вопросам в сфере преступлений против общественной нравственности.

Ключевые слова: преступления против общественной нравственности, жестокое или насильственное обращение с несовершеннолетними, принуждение заниматься проституцией, вовлечение лица в проституцию, совершение сутенерства, здоровье населения, организация или содержание притонов для занятия проституцией, оборот детской порнографии, духовно-нравственное здоровье личности, правовой опыт, особенности квалификации, преступления против общественной нравственности.

нравственному, физическому и психическому состоянию и развитию.

Исследование зарубежного опыта государств ближнего зарубежья регулирующего преступления против общественной нравственности позволяет сделать следующие выводы:

- во-первых, самостоятельным объектом охраняемых уголовным законом является нравственность. Это подтверждается уголовным законом изучаемых стран;

- во-вторых, преступления, направленные на сек- 
суальную эксплуатацию в отношении несовершеннолетних во многих странах наказываются довольно жестко и строго.

Зарубежные правовые нормы позволяет нам сформулировать ряд правовых понятий, как:

- сутенерство, то есть использование в целях наживы лица, занимающегося проституцией;

- отправление лица с его согласия в иностранное государство для сексуального использования;

- порнография детская;

- вовлечение в порнобизнес несовершеннолетнего;

- угроза нравственности лиц, не достигших шестнадцатилетнего возраста;

- сексуальная эксплуатация несовершеннолетних» представляет собой деяния общественно опасные, посягающие на сексуальные права и интересы несовершеннолетнего.

Так, законодателем Латвии дано определение жестокого или насильственного обращения с несовершеннолетним, а также установлено зависимое положение лица, что является актуальным и для отечественного уголовного законодательства.

Интерес представляют положения статьи 163 УК Латвии, где предусмотрена ответственность за нарушение правил, ограничивающих проституцию, совершенное повторно в течение года, то есть конкретного и определенного периода времени.

В статье 165 УК Латвии установлена ответственность за сутенерство. В диспозиции данной нормы закона дано правовое понятие «сутенерства» и установлена конкретная цель совершения такого преступления, в российском уголовном законодательстве такое правовое понятие отсутствует, однако в практике подобные деяния имеются.

Считаем, что законодательное закрепление квалифицирующих признаков сутенерства, а именно совершение сутенерства группой лиц по предварительному сговору или в отношении малолетних лиц, представляет наибольший интерес для квалификации преступлений против общественной нравственности, поскольку несовершеннолетние и малолетние лица являются менее защищенными и не всегда способны защищать свои права и законные интересы. Это вызвано необходимостью более эффективного предупреждения совершений преступлений против несовершеннолетних и направлено на защиту их прав и интересов.

Установлено, что преступление может быть совершено в целях наживы или в отношении несовершеннолетнего, организованной группой или совершенно в отношении малолетнего.
Однако понятие «отправление лица с его согласия в иностранное государство для сексуального использования» является актуальным для отечественной судебной практики.

В статьях 137-140 УК Грузии установлена ответственность за «изнасилование, «насильственные действия сексуального характера», «понуждение к половому сношению или иным действиям сексуального характера», «половое сношение или иные действия сексуального характера с лицом, не достигшим шестнадцатилетнего возраста, мужеложство, лесбиянство или иные сексуальные контакты совершеннолетнего в извращенной форме с лицом, заведомо для виновного не достигшим шестнадцатилетнего возраста.

В статье 253 уголовного закона Грузии установлена ответственность за вовлечение в занятие проституцией путем применения насилия или угрозы насилием, или уничтожением имущества, шантажа или обмана, которое наказывается штрафом или лишением свободы на срок до двух лет.

Ответственности за данное деяние подлежит и юридическое лицо, которое наказывается штрафом, лишением права заниматься деятельностью или ликвидацией.

Для отечественного уголовного права данные правовые положения являются новым, на которые следует обратить внимание.

В статье 2552 уголовного закона Грузии предусмотрена ответственность за предложение о встрече лицу, заведомо не достигшему шестнадцатилетнего возраста, сделанное совершеннолетним с использованием информационных и коммуникационных технологий с целью совершения в отношении него преступления, если за таким предложением последовали действия, направленные на проведение такой встречи, которое наказывается ограничением свободы на срок до трех лет или лишением свободы на срок от одного до трех лет [3].

Данная правовая норма закона, несомненно, является актуальной и перспективной, поскольку позволяет предотвратить совершение преступлений против общественной нравственности в отношении несовершеннолетних.

Уголовное законодательство Армении предусматривает ответственность за преступления против общественной нравственности в главе 18 «Преступления против общественной безопасности, безопасности компьютерной информации, общественного порядка, общественной нравственности и здоровья населения», куда входят преступления против половой неприкосновенности и половой свободы. 
В статье 166 уголовного закона Армении установлена ответственность за вовлечение ребенка в систематическое употребление алкогольных напитков, в немедицинское употребление сильнодействующих или иных одурманивающих веществ, в проституцию, бродяжничество или попрошайничество, в совершение действий, связанных с изготовлением материалов или предметов порнографического характера, совершенное лицом, достигшим восемнадцатилетнего возраста, которое наказывается исправительными работами на срок не свыше одного года, либо арестом на срок от одного до трех месяцев, либо лишением свободы на срок не свыше пяти лет.

Установлена уголовная ответственность за данное деяние совершенное родителем, педагогом или иным лицом, на которое возложена обязанность по воспитанию ребенка, что может найти практическое применение и в нашем законодательстве.

В соответствии с уголовным кодексом Республики Казахстан преступления против общественной нравственности урегулированы в разделе 11 «Уголовные правонарушения, преступления против здоровья населения и нравственности», где предусмотрена уголовная ответственность за совершение следующих преступлений. А именно: «вовлечение в занятие проституцией путем применения насилия или угрозы его применения, использования зависимого положения, шантажа, уничтожения или повреждения имущества либо путем обмана» (ст.308); «организация или содержание притонов для занятия проституцией, а равно сводничество с корыстной целью, то же деяние совершенное группой лиц по предварительному сговору; неоднократно; и сопряженное с вовлечением несовершеннолетнего в занятие проституцией, которое наказываются лишением свободы на срок от пяти до десяти лет с конфискацией имущества» (ст.309).

Следует обратить внимание, что в данной правовой норме законодателем установлена ответственность за организацию или содержание притонов для занятия проституцией, а равно сводничество с корыстной целью, что представляет огромный интерес, поскольку практика имеет широкий круг таких противоправных деяний [5].

Такой состав преступления как незаконное распространение произведений пропагандирующих культ жестокости и насилия содействует мерам предупреждения преступлений и обеспечивает нравственное и физическое развитие несовершеннолетних.

Уголовный кодекс Республики Азейбарджан в главе 22 «преступления против несовершеннолетних и семейных отношений» предусматривает ответственность за преступления против общественной нравственности. К таким составам преступлений относятся вовлечение несовершеннолетнего в занятие проституцией, либо совершение аморальных действий,

Квалифицированным составом преступления является то же деяние совершенное с применением насилия или с угрозой его применения, организованной группой, родителями несовершеннолетнего лица или другими лицами, на которых законом возложена обязанность по воспитанию несовершеннолетнего, либо учителем или другим работником образовательного, воспитательного, медицинского или иного учреждения, на которого возложена обязанность по осуществлению надзора над совершеннолетними, которое наказываются лишением свободы на срок от четырех до восьми лет (ст.171).

Законодательно установлена ответственность за оборот детской порнографии, под которой понимается распространение, рекламирование, продажа, передача другим, отправление, предложение, создание условий для приобретения, либо изготовление, приобретение или хранение с целью распространения или рекламы детской порнографии.

При этом, в примечании к данной норме закона дается определение детской порнографией под которой подразумеваются любые предметы или материалы, которые отражают участие несовершеннолетнего или лица, создающего образ несовершеннолетнего, в реальных или симулированных действиях явно выраженного сексуального характера, либо отражают половые органы несовершеннолетних в сексуальных целях, в том числе реалистичные изображения, которые отражают несовершеннолетнего, участвующего в явно выраженных сексуальных действиях.

В силу положений уголовного кодекса Кыргызской Республики преступления против общественной нравственности урегулированы в главе 26, которая называется «Преступления против духовно-нравственного здоровья личности».

Следует отметить, что в самом названии данной главы уголовного закона заложено понятие нравственности и влияние преступного деяния на духовное здоровье человека.

Для практического применения интерес представляет такой состав преступления против общественной нравственности, как вовлечение заведомо несовершеннолетнего в порнобизнес.

Под порнобизнесом понимается, вовлечение заведомо несовершеннолетнего в действия, связанные с изготовлением предметов порнографического характера, 
или в качестве исполнителей для участия в мероприятиях порнографического характера, а равно изготовление произведения, изображающего несовершеннолетнего в эротической или порнографической ситуации, или копий такого произведения. Квалифицирующими признаками данного преступления выступают действия совершенные с применением насилия, не опасного для жизни и здоровья, или угрозы его применения, уничтожения либо повреждения имущества, шантажа или обмана, родителем или иным лицом, на которое законом возложены обязанности по воспитанию несовершеннолетнего, а равно педагогом или другим работником образовательного, воспитательного, лечебного либо иного учреждения, на которое законом возложены обязанности осуществлять надзор за несовершеннолетним.

В соответствии с положениями уголовного кодекса Республики Таджикистан от 21 мая 1998 г. в разделе 10 «Преступления против общественного порядка и нравственности», где урегулирована ответственность за преступления против общественной нравственности.

Так, например, к таким преступлениям относится вовлечение в занятие проституцией, которое совершается путем применения насилия или угрозы его применения, использования зависимого положения, шантажа, угрозой, уничтожения или повреждения имущества либо путем обмана, совершенное повторно или организованной группой, которое наказывается штрафом в размере от одной до двух тысяч показателей для расчетов или лишением свободы на срок от двух до пяти лет (ст.238). Организация или содержание притонов, сводничество либо сутенерство», которое включает организацию или содержание притонов для занятий проституцией, а равно сводничество из корыстных побуждений или сутенерство, то же деяние, совершенное повторно или организованной группой, наказывается лишением свободы на срок от пяти до восьми лет» (ст.239).

Общим для всех рассмотренных составов преступлений против общественной нравственности является понятие нравственности, под которым понимается правило, для воли, совести человека, это особая форма общественного сознания и вид общественных отношений, духовные и душевные качества человека, основанные на идеалах добра, справедливости, долга, чести, вероисповедания и еще огромного комплекса понятий, которые проявляются в отношении к другим людям и природе.
Итак, говоря о преступлениях против общественной нравственности, следует сказать, что соблюдение и защита духовно-культурных прав человека предполагает особую защиту со стороны общества и государства.

Закономерностью нашего времени становится более расширяющаяся самостоятельная жизнь общества. Ее цели: духовная и социальная миссии, воспитание, нравственность, а особенно - обеспечение мира и согласия в обществе, предупреждение враждебности, ненависти.

Практически во всех государствах, как ближнего, так и дальнего зарубежья уголовным законом урегулирована уголовная ответственность за преступления против общественной нравственности. При этом, наиболее строгое наказание предусмотрено за вовлечение в занятие проституцией, организацию и содержание притонов для занятия проституцией, сутенерство либо сводничество, что говорит об их общественной опасности для общества.

Исследование проблем нравственных ценностей и связи уголовно-правовых норм с нормами общественной нравственности, показывает, что нормы нравственности выступают неформальным средством регулирования поведения людей и общественных отношений. Они направлены на развитие нравственного самосознания личности с опорой на распространенные в обществе взгляды и убеждения.

Нормы нравственности требуют от личности не только соблюдения законов, но и превращения их в личное убеждение и привычку.

Следовательно, именно нравственность является тем единственным фундаментом, который способен объединить как наше общество, так и человечество в целом.

Считаем, что данный правовой опыт достоин внимания российского законодателя и его необходимо самым тщательным образом систематизировать и изучить, чтобы использовать наиболее рациональные, эффективные элементы в практической деятельности.

Вопросы исследования преступлений против общественной нравственности являются актуальными как для научного толкования, так и для практики применения уголовного законодательства.

\section{ЛИТЕРАТУРА}

1. Уголовный кодекс Латвийской Республики / Науч. ред. и вступ. ст. канд. юрид. наук А.И. Лукашова и канд. юрид. наук Э.А. Саркисовой; перевод с латышского канд. юрид. наук А.И. Лукашова. СПб.: Юридический центр Пресс, 2001. С. 320

2. Уголовный кодекс Литовской Республики. СПб., 2002. С 112 
3. Уголовный кодекс Грузии. СПб., 2002. С.32

4. Уголовный кодекс Республики Армения от 29 апреля 2003 г. N 3Р-528 (в ред. от 14.01.2017) // Официальные ведомости (вестник) Республики Армения. 2003. N 25 (260). Ст. 407.

5. Уголовный кодекс Республики Казахстан. СПб., 2001 С. 88

6. Уголовный кодекс Кыргызской Республики от 1 октября 1997 г. N 68 (в ред. от 02.08.2017) // Ведомости Жогорку Кенеша Кыргызской Республики. 1998. N 7. Ст. 229.

7. Уголовный кодекс Республики Таджикистан // Права человека: сборник международных и национальных документов в 8 томах / отв. ред. к.ю.н. Диноршоев А.М. Т. 6. Душанбе, 2009. С. 80 - 85,117.

8. Уголовный кодекс Республики Узбекистан / Вступ. ст. М.Х. Рустамбаева, А.С. Якубова, 3.Х. Гулямова. СПб.: Издательство «Юридический центр Пресс», 2001. С. 338

9. Уголовный кодекс Республики Беларусь / Предисл. Б.В. Волженкина. - СПб.: Издательство «Юридический центр Пресс», 2001. С. 474

10. Уголовный кодекс Туркменистана от 12 июня 1997 г. N 222-1 (в ред. от 25.11.2017) // Ведомости Меджлиса Туркменистана. 1997. N 2. Ст. 9, 14.

(с) Ярошенко Ольга Николаевна (olga.yaroshenko.74@bk.ru).

Журнал «Современная наука: актуальные проблемы теории и практики»

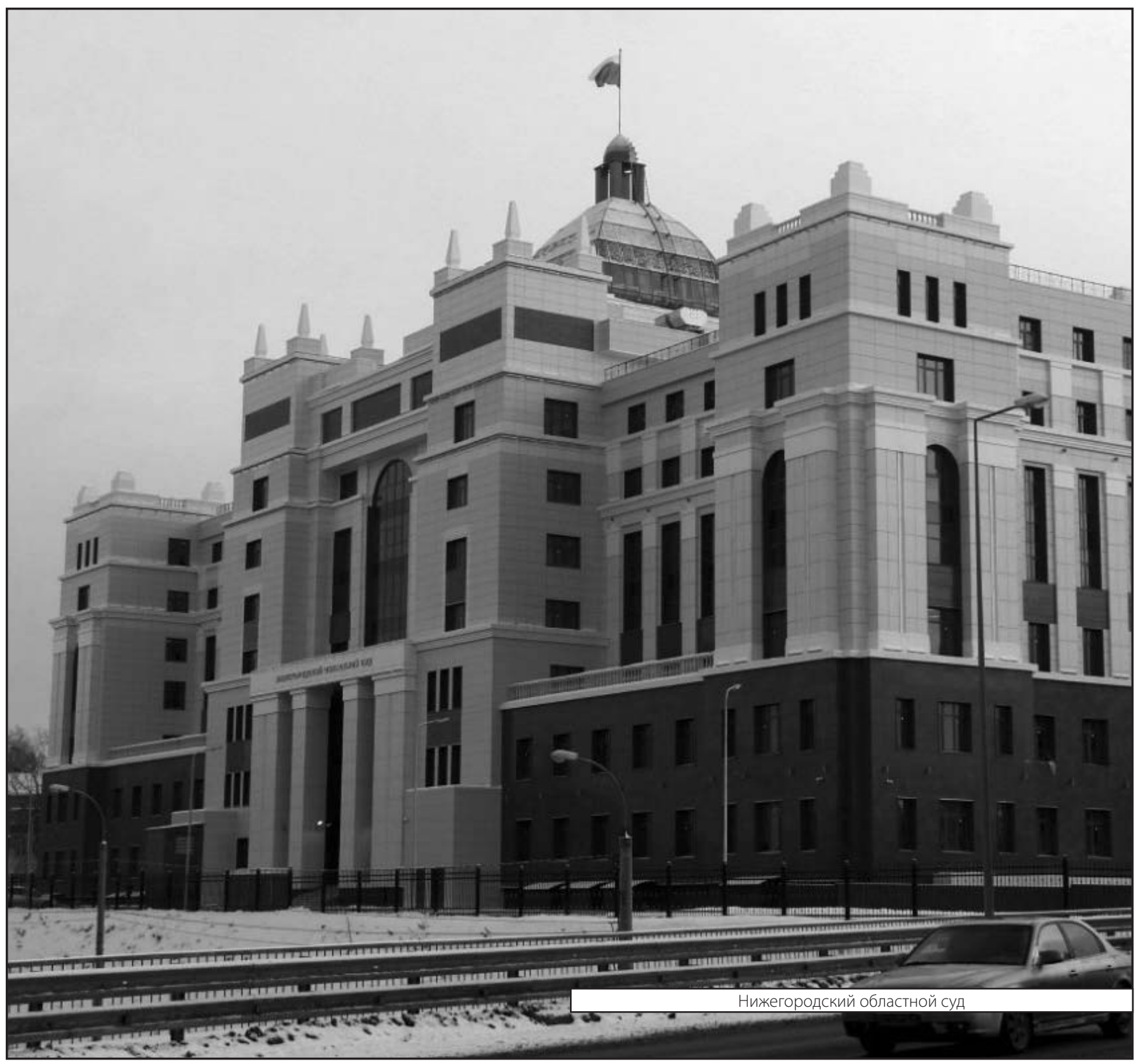

